\title{
Study of Energy Consumption Pattern in Sri Lankan Rice Mills - Enhancing Opportunity for Conservation
}

\author{
M S M Roomi, D D A Namal, and K T Jayasinghe
}

\begin{abstract}
The consumption of direct energy in the semi modern and modern Sri Lankan rice mills were studied to determine the energy consumption pattern, in order to enhance the energy conservation opportunities. In this paper, energy audit surveys of six-rice mills are presented from major rice processing districts of Polonnaruwa and Anuradhapura, which are geographically located in the North Western Province of Sri Lanka. Electrical and thermal energy, daily electrical consumption, husk utilization and boiler evaporation data were recorded and annual production and energy data were also collected. These data were evaluated in terms of the electrical and thermal specific energy, daily electrical and thermal energy consumption patterns, thermal and electrical sharing percentage and boiler efficiency. On an average basis, specific energy required to produce one ton of rice in semi modern and modern rice mills are as follows: electrical energy requirement is $42.84 \mathrm{kWh} /$ ton and 41.10 $\mathrm{kWh} /$ ton respectively; thermal energy requirement for both drying and parboiling is $917 \mathrm{MJ} /$ ton and $1092 \mathrm{MJ} /$ ton respectively. During this process, boiler efficiency was about $30 \%$ while utilizing $95 \%$ of husk produced in the rice mills.
\end{abstract}

Key Words: Energy, husk, rice milling, cogeneration, energy consumption pattern, alternative energy source, parboiling, steam, Energy conservation

\section{Introduction}

Rice is the staple food of half the world's population. It is also the staple food in Sri Lanka and approximately 2.8 million metric tons of paddy (rough rice) is produced annually. Rice processing is acknowledged to be the largest agro based industry in the country, turning more value of product than any other industry [12]. Rice processing is carried out in several parts of the country and there are about 7000 mills in operation in Sri Lanka. However, more than $42 \%$ (around 2940) of rice processing mills come under the category of semi modern or modern rice mills. These rice processing mills produce husk ( $20 \%$ of paddy) at the rate of more than 200 $\mathrm{kg} / \mathrm{hr}$ because these mills have the paddy processing capacity of more than 1 ton/ hr [14].

There are two types of rice available in the Sri Lankan market as parboiled and raw rice. In the case of raw rice, the paddy is processed without any treatment. However, parboiled rice is produced by subjecting to a soaking, steaming and drying treatment to paddy. Rice milling is the removal and separation of the husk (dehusking) and the bran (polishing) to produce the edible portion (endosperm) for human consumption.
Rice processing operations require electrical energy to run the machines specially to rotate the electrical motor. And thermal energy is required for parboiling, soaking and drying operations of paddy. The parboiling process is used to increase the moisture content of paddy from $14 \%$ to $36 \%$. However it is brought down again to $14 \%$ through drying operation for milling purposes. The Miller does not have an idea about the specific energy consumption in rice processing and there is no proper study on Sri Lankan rice mills of energy consumption per $\mathrm{kg}$ of rice produced.

This study was conducted to evaluate the electrical and thermal energy consumption pattern of the rice mills to understand the specific energy consumption per $\mathrm{kg}$ of rice produced, and to ascertain husk availability in the rice mills as a potential energy source.

Eng.M.S.M.Roomi, BSCEng. AMIChemE(UK). AMIE(SL). Chemis:n Engineer, Energy and Environmental Management Ceutre. National Engineering Research and Development Centre.

Eng.D.D.A.Namal, BScEng (IIon.), MIE (SL), CEng.. MEng (Energy Technology). Head, Energy and Environmental Management Cenire. National Engineering Reseanch and Development Centre.

Eng.K.T.Jayasinghe, BSrEng (Hon.), AMIE(SL), Mechaniral Engineer. Energy and Envinommental Manngemen Centre. National Engineering Research and Development Centre. 


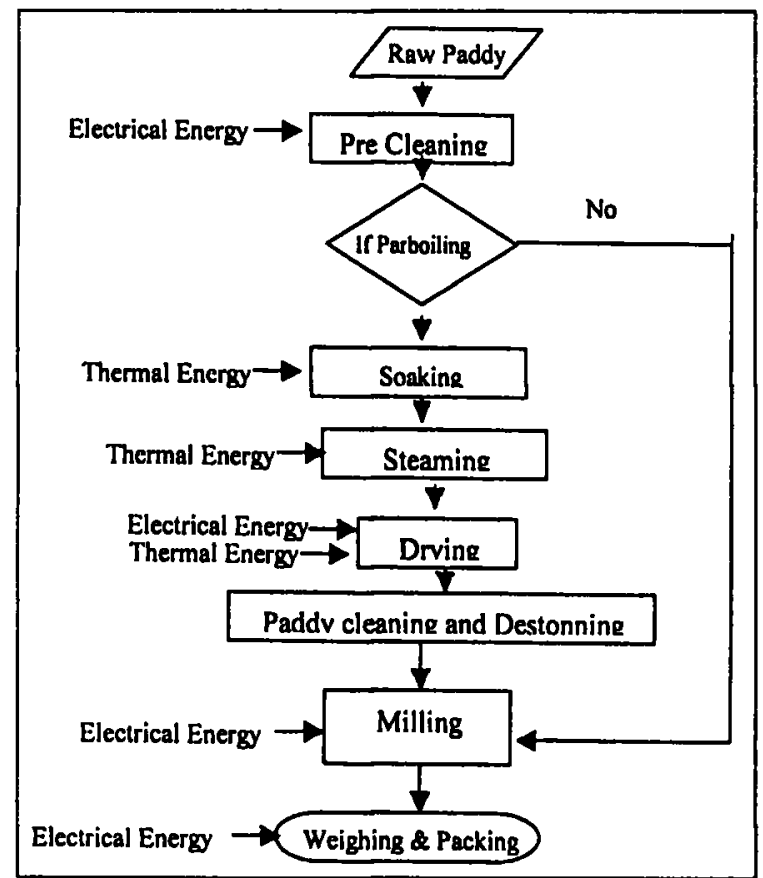

Figure 1 : Rice processing flow diagram

\section{Rice processing}

The first step in the rice milling process is the paddy cleaning. During this operation paddy is cleaned to remove the impurities other than the paddy and same size stones as paddy.

The cleaned paddy is subjected to parboiling. This process involves three basic steps of soaking, steaming and drying operations. Soaking operation has been practiced in two ways. The first method is cold soaking, which is carried out in ordinary water $\left(27^{\circ} \mathrm{C}\right)$ for one or two days or more according to the variety and freshness of the paddy. The second way of soaking is hot soaking, where the paddy is steeped in hot water at $60^{\circ} \mathrm{C}$ $70^{\circ} \mathrm{C}$ for $3 \mathrm{hrs}$ to $4 \mathrm{hrs}$. This hot water is produced using an electrical heater, a steam heat exchanger or direct steam. The soaking operation increases paddy moisture content from $14 \%$ to $26 \%$. Soaked paddy is subjected to $4-5$ minutes direct steaming, according to the variety, at high steam pressure to increase the kernel moisture from $26 \%$ to $36 \%$.

Rice processing requires paddy with less than $14 \%$ (wet basis) moisture. Therefore, a drying operation is carried out in two ways either as sun drying (natural) or artificial drying. Sun drying is the most common practice in Sri Lanka. However, these mills have artificial dryers also to compensate during the rainy season. In contrast to that, some mills only use the mechanical drying for this purpose. The hot air is generated for drying by using steam through the heat exchanger which is assisted with a blower, and it has a elevator and flow regulator to circulate the paddy in the dryer to get uniform drying.

After drying, paddy is fed to the rubber roll paddy husker to strip off the husk. This operation produces $70-80 \%$ husked paddy mixed with unhusked paddy. The paddy separator is used to separate the rice from the paddy. This brown rice is exposed to the whitening and polishing operation; the bran layer is removed $(8-10 \%)$, for producing the brilliant white rice with little rice bran attached to the surface. Some millers have wet polishers to polish the rice to remove the total bran and oil content on the grain of rice and help to increase the yield and make the surface smooth and shining. Then, rice is graded by using the length grader or sieve of wire woven net to produce whole grain separated (more than $1 / 2$ size) from the broken grain. This whole grain is passed through the Colour sorter to remove the discoloured and black grain from the white rice.

\section{Boiler}

A Boiler is used to produce the live steam for parboiling and drying of the paddy in the rice mill. However, in some cases, steam is used for soaking of the paddy too. The Boiler is operated on direct firing of paddy husk in the boiler furnace. Two types of boilers are used in the rice mills; these are the vertical type and the horizontal type boiler; otherwise single or three pass fire tube boiler with the help of FD or/and ID fan. Water is fed to the boiler by diffuser or centrifugal pump. It is pressurized to 100 Psig and steam-evaporating capacity is varying according to the mills.

\section{Conveyors}

This is also a major energy consuming operation in the rice mills. These conveyors are used to transfer the paddy/ rice from one operation to another, and most of the time conveyors are mechanical bucket type elevators. It consists of a motor in the power range of $1-3 \mathrm{hp}$ single phase.

\section{Material \& Methodology}

In order to undertake the energy consumption pattern, six rice mills of different capacities w'ere selected from major rice processing districts of 
A'pura, Polonnaruwa and Ampara for this survey. These rice mills are categorised based on following factors.

1. Production Capacity $<1.5$ ton $/ \mathrm{h}$, semi modern (medium scale, greater than 1 ton / h) rice mills

2. Production capacity $>=1.5$ ton $/ \mathrm{h}$, modern (Large scale) rice mills.

Daily Electricity consumption: Energy analyzer (Data Logger; VIP 3 Energy analyzer) was installed at the Ceylon Electricity Board (CEB) main supply panel of the rice mill to record the $\mathrm{kW}, \mathrm{kVA}, \mathrm{kVAr}$, Powerfactor, current and voltage against the time. This Data logger is programmed to monitor the 15-minute sampling intervals of integrated average for twenty-four hours. CEB meter reading also have been taken for increasing the reliability of data. The rice mills were maintained at normal operation during the survey.

Husk utilization percentage: Husk is quantified from the total paddy taken for production in the rice mill, that is, $20 \%$ of husk produced from total milled paddy. On site husk utilization by the rice mill, (feeding rate of husk to the boiler), is taken with the time. and the consumption rate of husk is calculated by dividing quantity of husk with duration of feeding. The ratio of husk production and utilization on site is ratio of quantity of paddy husk utilized in the boiler to total quantity of paddy husk produced as a byproduct from rice processing.

Boiler Evaporation \& Efficiency: Boiler efficiency is calculated from husk fuel energy feed to the boiler divided by energy in the water evaporated during this period. Rate of evaporation and feed is calculated by dividing the water and paddy husk consumed by boiler with the time taken. The assumption was made that all steam evaporated in the boiler is used for parboiling or drying or otherwise both together.

Energy Consumption: Electrical energy consumption of $\mathrm{kWh}$ was converted to MJ by using the 3.6-converting factor. Similarly, thermal energy consumption for the process was calculated from the boiler pressure and rate of water evaporated. The steam table was used to get the energy content according to the temperature and pressure of steam. Thermal energy input for rice processing from the solid fuel is obtained by total consumption of paddy husk to the boiler. It is converted to thermal energy by using a converting factor of $13.5 \mathrm{MJ} /$ $\mathrm{kg}$.

Energy consumption per ton of made rice: Energy required per ton of made rice was calculated from the production and energy consumption value of each rice mills. Contribution made by the electricity and husk fuel used for producing one ton of rice as a percentage of total energy consumption has also been determined. The data of electrical consumption and production have been collected for one-year; that is through the monthly electricity bill and production statistics from the rice millers to evaluate the specific energy in the rice mill.

Table 1 Details of rice mills surveyed

\begin{tabular}{|l|l|c|l|}
\hline $\begin{array}{c}\text { Rice } \\
\text { Mill }\end{array}$ & $\begin{array}{c}\text { Type of the } \\
\text { Mill }\end{array}$ & $\begin{array}{c}\text { Capacity } \\
\text { (tons/day) }\end{array}$ & $\begin{array}{c}\text { Processing } \\
\text { rice type }\end{array}$ \\
\hline F1 & Modern & 26 & Raw and Parboiled \\
F2 & Semi modern & 12 & Parboiled \\
F3 & Modern & 24 & Raw and Parboiled \\
F4 & Modern & 24 & Parboiled \\
F5 & Semi modern & 12 & Parboiled \\
F6 & Semi modern & 11 & Parboiled \\
\hline
\end{tabular}

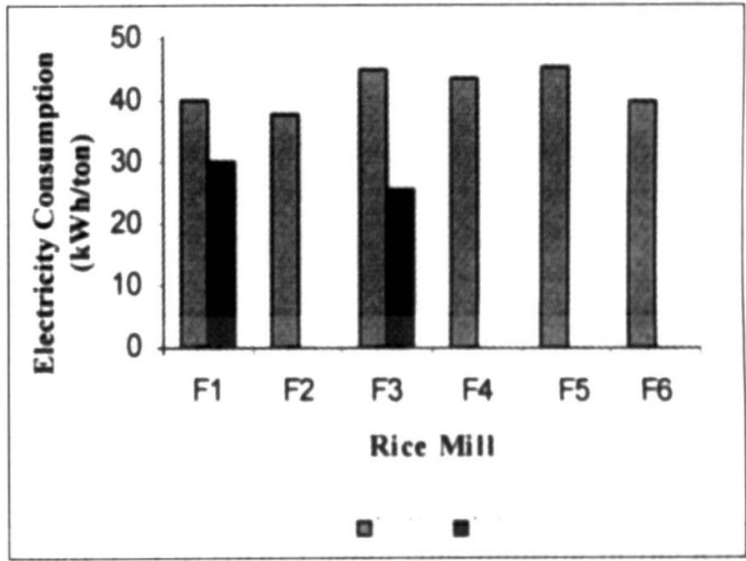

Figure 2 : Electrical Energy consumption in the Rice Mill

\section{Results and Discussion}

Electrical energy consumption: Fig 02 shows the electrical energy consumption of one ton of paddy processing for modern and semi modern rice mills. Semi modern rice mills: electrical energy consumption varies from $35.72 \mathrm{kWh} /$ ton to $45.59 \mathrm{kWh} /$ ton and in modern rice mill consumption varies in the range of $40.04 \mathrm{kWh} /$ ton to $44.91 \mathrm{kWh} /$ ton. However, rice mills F1 
and $\mathrm{F} 3$ have been producing raw rice too. In these raw rice milling process, electrical energy consumption varys from 25.3 to $29.8 \mathrm{kWh} /$ ton. The variations in the power consumption depend on the types and number of machines with different power ratings and the operating pattern subjected to rice processing. On an average basis, semi modern rice mills consume $41.10 \mathrm{kWh} /$ ton with 1.94 standard deviation and modern rice mills consume $42.84 \mathrm{kWh} /$ ton with 1.2 standard deviation. Similarly for a raw rice mill the average electrical consumption is $27.55 \mathrm{~kW} /$ ton with a standard deviation of 1.6 .

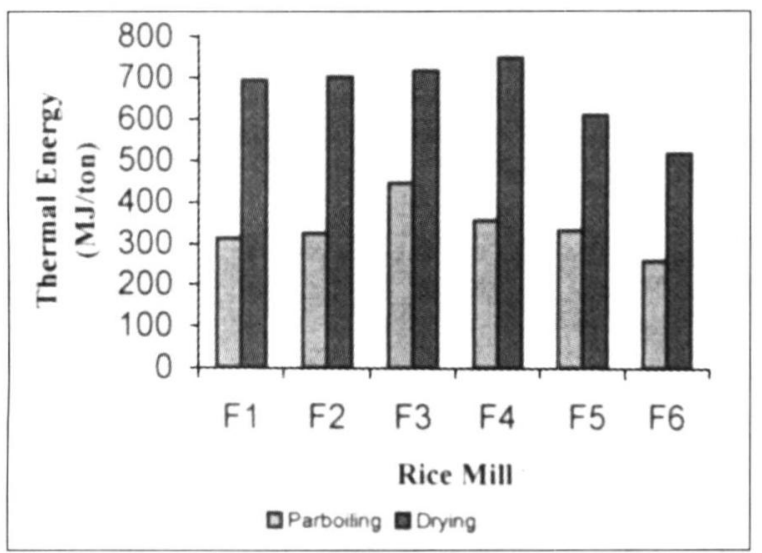

Figure 3: Thermal Energy Consumption in Rice Mills

Thermal energy consumption: Fig 03 shows the thermal energy consumption for parboiling and drying operations in the rice mills. Thermal energy consumption in the modern and semi modern rice mills for parboiling varies in the ranges of $258.01 \mathrm{MJ} /$ ton to $332.92 \mathrm{MJ} /$ ton and $312.19 \mathrm{MJ} /$ ton to $446.19 \mathrm{MJ} /$ ton respectively. Similarly thermal energy consumption of the modern and semi modern rice mills for drying varies from $519.40 \mathrm{MJ} /$ ton to $703.89 \mathrm{MJ} /$ ton and $694.12 \mathrm{MJ} /$ ton to $750.60 \mathrm{MJ} /$ ton respectively. This variation occurred due to leakages in the steam line, lack of maintenance and improper selection of accessories (Boiler ID \& FD fan, steam trap and Insulation.). However, F6 is consuming the least thermal energy due to re-circulation of condensate to the boiler, even though it does not have the proper insulation and maintenance. On an average basis the parboiling process of semi modern rice mills consume $305.36 \mathrm{MJ} /$ ton with a standard deviation of 19.5 and modern rice mills consume $371 \mathrm{MJ} /$ ton with a standard deviation of 32.2. Whereas the drying process of semi modern rice mills consume $612 \mathrm{MJ} /$ ton with a standard deviation of 13.32 and modern rice mills consume $721 \mathrm{MJ} / \mathrm{kg}$ with a standard deviation of 43.5 .

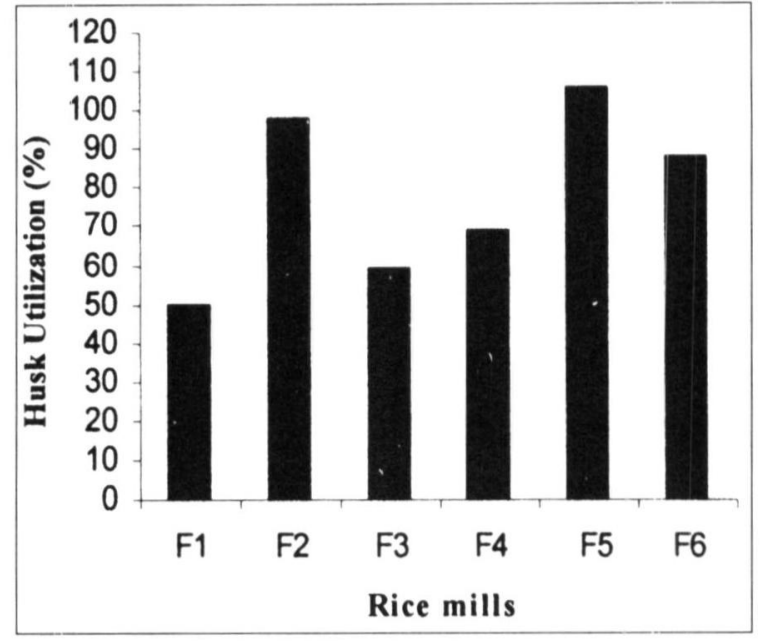

Figure 4: Husk utilization percentage

Husk Utilization: Fig 04 shows the husk utilization percentage in the rice mills. Modern rice mills utilization varies between $50 \%$ and $98 \%$. However, F1 and F3 utilization is very low due to raw rice production husk availability. Semi modern rice mill utilization varies between $88.6 \%$ and $105.19 \%$. However, F6 consumes less than other semi modern rice mills due to recirculating the condensate to the boiler.

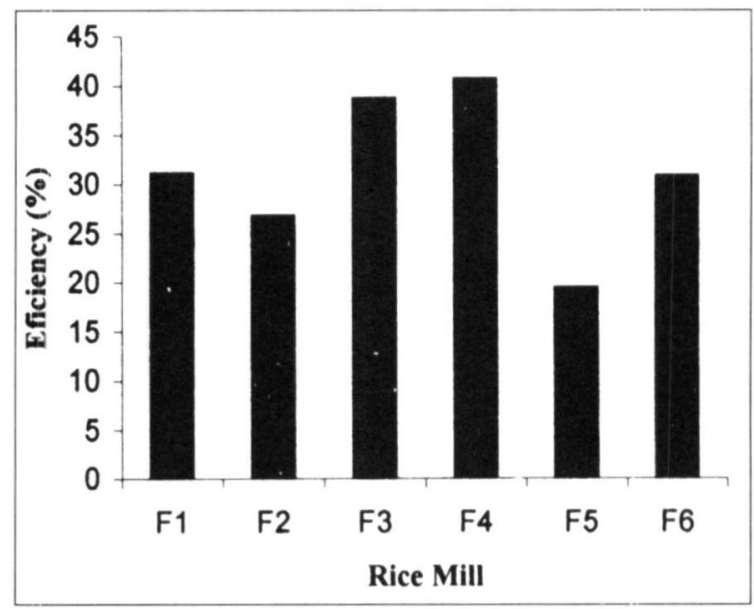

Figure 5: Boiler efficiency in the Rice Mill

Boiler Efficiency: Fig 05 shows boiler efficiency during the parboiling and drying in the rice mills. Semi modern rice mills boiler efficiency varies between $19.34 \%$ and $30.74 \%$. However, modern rice mill boiler efficiency varies between the $31 \%$ and $40.60 \%$. These variations occur due to the combustion efficiency, retention time of flue gas and maintenance of boiler.

Energy Sharing: Fig 06 shows the energy sharing percentage between electrical and thermal energy in the rice mills. Electrical energy sharing of modern rice mills range from $7.5 \%$ to $19.99 \%$ and thermal energy sharing varies between 


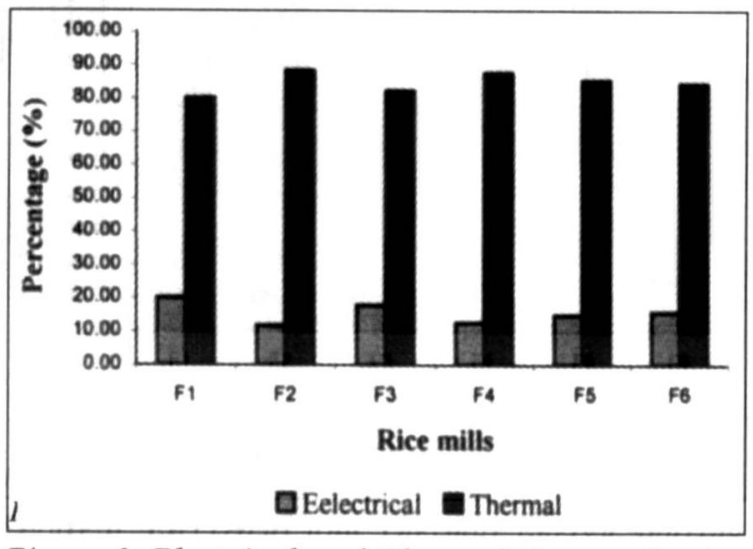

Figure 6: Electrical and Thermal Energy sharing percentage in the rice mill

$80.01 \%$ and $92.4 \%$. However in semi modern rice mills electrical energy sharing varies between $6.04 \%$ and $15.37 \%$ and thermal energy sharing range from $84.31 \%$ to $93.96 \%$ respectively.

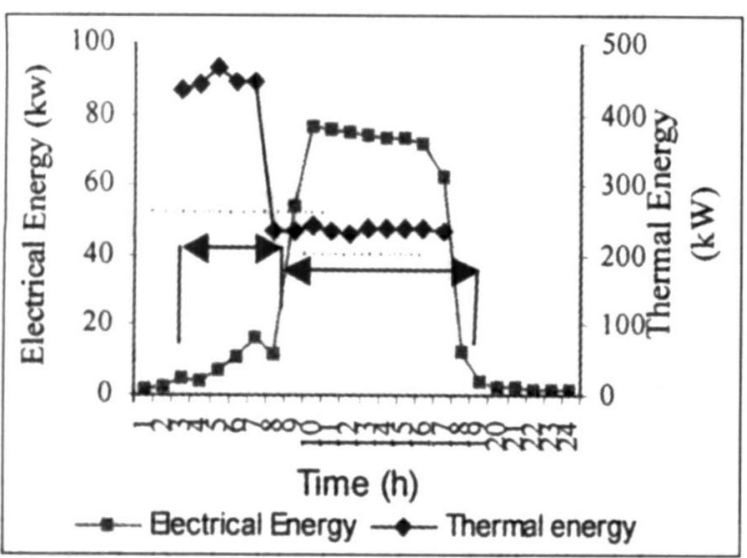

Figure 7: Daily Electrical and Thermal Energy Consumption Pattern

Daily electrical and thermal load pattern: Fig 07 shows the daily electrical and thermal energy consumption pattern in a semi modern rice mill for parboiled rice processing having a capacity of 11 ton/day. The parboiling process started at $0200 \mathrm{~h}$ and ended at $0700 \mathrm{~h}$ and this operation consumes thermal energy at an average of 445 $\mathrm{kW}$, However, the dryer was started at $0400 \mathrm{~h}$ and circulates the parboiled paddy to cool down. The drying operation was begun at 0700 hrs with hot air up to $1700 \mathrm{hrs}$. The average electrical and thermal energy consumption is 20 $\mathrm{kW}$ and $236 \mathrm{~kW}$ respectively. Electrical energy consumption has suddenly increased to $80 \mathrm{~kW}$ due to the milling process while drying is carried out in the rice mill and this peak demand continues from $0800 \mathrm{hrs}$ to $1800 \mathrm{hrs}$.

\section{Conclusion}

1. The variation in the rate of electrical energy consumption $\mathrm{kWh} /$ ton is less compared to that of the husk utilization. It indicates the better control of the use of electrical energy

2. Thermal energy consumption has a very high standard deviation due to steam leaks, no insulation, unnecessary piping, improperly selected and maintained steam traps.

3. Efficiency of the boiler in the modern and semi modern rice mills is very low due to the poor energy conversion and transferring methods.

4. The share of the thermal energy is very much greater than the electrical energy in the rice mill

5. Rice mills have the potential to carry out cogeneration in the rice mill; therefore a techno economical feasibility study is required.

6. Rice mills have the potential to reduce the thermal and electrical energy consumption in the rice mills by proper maintenance, house keeping and machine selection.

\section{References}

1. Abdur Rahman M, Miah AK, Ahmed A. Status of rice processing technology in Bangladesh. Agricultural Mechanization in Asia, Africa and Latin America, Vol. 27, No.1, 1996,pg 46:50

2. Akira H. Rice Post Harvest Technology. Ministry of Agriculture Forestry and Fisheries, Japan. March 1995.

3. Alvarado S, Maldonado P, Barrios A. Long term energy related environmental issues of copper production. Energy 22 (2002) 183-196.

4. Baruah DC, Bhattacharyya PC. Energy Utilization Pattern in the Manufacture of Black Tea. Agricultural Mechanization in Asis, Africa and Latin America, Vol. 27, No.4, 1996,pg 65:70

5. Ezeike GOI. Energy Consumption in Rice Processing Operation in Nigeria: Selected Case Study. Agricultural Mechanization in Asia, Africa and Latin America, Vol. 18, No.1, 1987,pg $33: 40$

6. Sookkumnerd C, Ito N, Kito K. Financial viability of husk-fuel steam engine as energy saving technology in Thai rice mill. Applied energy 82 (2005) $64-80$. 
7. Farahbakhsh $\mathrm{H}$, Ughursal Vifung AS. A residential end user energy consumption model for Canada. Int. J. Energy Res. 1998;22:1133-43

8. Geoffrey KF Tso, Yau KKW. A study of domestic energy usage patterns in Hong Kong. Energy 28 (2003) 1671 - 1682.

9. James J, Spadaro, Jack Mathews, James I And Wadsworth. Milling Rice: Production and Utilization, Edited by Luh, S. 1980, 360 - 402.

10. Palaniappan C, Subramanian SV. A Study and Analysis of Energy Consumption Patlern In Tea Factories of South India - For Energy Conservation Solution. Agricultural Mechanization in Asia, Africa and Latin America, Vol. 29, No.2, 1998,pg 12:16

11. Palipane K.B. Milling and quality improvement in rice, the rice symposium 14 - 15 December 2000. Department of Agriculture, Gannuoruwa, Sri Lanka
12. Roomi MSM, Senanayake DP, Palioane DP. Evaluation of milling performance with different types of rice polishing machines available in Sri Lanka. Transaction 2004, Institution of Engineers, Sri Lanka, Vol I Part B, PP 229 - 235.

13. Senanayake DP, Daranakame $U$ and Fernando M.D. Rice husk availability and Consumption pattern in sri Lanka, Institute of Post Harvest Technology, Unpublished, 2001

14. Stipe DR, Wratten FT and miller MF. Effect of various method of handling brown rice on milling and other quality parameters. Proc. 14th rice tech. Working group, June 20 - 22, Devis, California. 1972.

15. Williams EA., Robinson AP. Survey of the equipment for small-scale motive power and electricity generation from wood and agricultural residuc. Chatham, UK, Natural Resource Institute, 1993. 